\title{
USEFUL DAYLIGHT ILLUMINANCE (UDI) PADA RUANG BELAJAR SEKOLAH DASAR DI KAWASAN URBAN PADAT TROPIS (STUDI KASUS: SD NEGERI 2 DAN 6 BANDA SAKTI, LHOKSEUMAWE, ACEH, INDONESIA)
}

\section{Atthaillah}

Program Studi Arsitektur, Universitas Malikussaleh

atthaillah@unimal.ac.id

\author{
Andik Bintoro \\ Jurusan Teknik Elektro, Universitas Malikussaleh \\ andik@unimal.ac.id
}

Naskah diajukan pada: 8 Juli 2019

Naskah revisi akhir diterima pada: 23 Oktober 2019

\begin{abstract}
Abstrak
Studi ini melakukan evaluasi pencahayaan alami pada ruang belajar Sekolah Dasar Negeri 2 dan 6 Banda Sakti, Lhokseumawe. Sekolah tersebut berada pada lokasi urban padat dan merupakan sekolah dengan bangunan terluas di kecamatan Banda Sakti. Ada 36 (tiga puluh enam) ruang kelas yang dilakukan simulasi pencahayaan alami pada objek studi ini. Simulasi pencahayaan alami dilakukan dengan metrik useful daylight illuminance (UDI). Metrik ini menggunakan data cuaca lokasi objek penelitian dalam hal ini data cuaca Kota Lhokseumawe dalam format energyplus weather $(E P W)$ file. Pemodelan untuk simulasi dilakukan dengan piranti Rhinoceros, sementara algoritma simulasi dibuat menggunakan Grasshopper dengan tambahan plugin Ladybug Tools. Ladybug Tools memberikan akses ke engine simulasi Daysim yang merupakan perangkat simulasi pencahayaan alami yang tervalidasi. Pada penelitian ini ketegori UDI terpenuhi dialterasi sesuai dengan standar pencahayaan alami disarankan dalam SNI 03-6197 yaitu 250-750 Lux untuk ruangan yang digunakan pada bangunan pendidikan dalam hal ini sekolah dasar. Hasil menunjukkan tidak ada ruang kelas yang dikategorikan baik pada SDN 2 dan 6 Banda Sakti. Hanya terdapat 29 (dua puluh sembilan) kelas dengan kategori cukup dan 7 (tujuh) ruang dengan kategori kurang.
\end{abstract}

Kata-kata Kunci: Pencahayaan Alami, Useful Daylight Illuminance (UDI), Simulasi Komputasi, Sekolah Dasar

\section{USEFUL DAYLIGHT ILLUMINANCE (UDI) IN ELEMENTARY SCHOOL CLASSROOMS IN TROPICAL HIGH DENSITY URBAN AREA (CASE STUDY: SD NEGERI 2 AND 6 BANDA SAKTI, LHOKSEUMAWE, ACEH, INDONESIA)}

\author{
Abstract \\ This study evaluated the daylight distribution within classrooms at Sekolah Dasar Negeri 2 \\ and 6 Banda Sakti, Lhokseumawe. The school is located in high-density urban area, and it was the
}


largest state elementary school building in Banda Sakti. 36 (thirty-six) classrooms were simulated for its daylight performance. The simulation utilized useful daylight illuminance (UDI) metric. The metric used the local weather file for Lhokseumawe in energyplus weather (EPW) format. Modeling for simulation utilized Rhinoceros; further, the simulation algorithm was created using Grasshopper with the extension of Ladybug Tools. Ladybug Tools opened access to a Daysim, a validated daylight simulation engine. In this study, the useful daylight was referenced to SNI 03-6197, which was 250-750 Lux for educational spaces at this study classrooms for the elementary school. The result showed there was none of the classroom fallen under a good category. 29 (twenty-nine) classrooms was under insufficient category and 7 (seven) classrooms under a bad category.

Keywords: Daylighting, Useful Daylight Illuminance (UDI), Computer Simulation, Elementary School

\section{Pendahuluan}

Pencahayaan alami yang baik dapat memberikan beberapa keuntungan dan manfaat kepada bangunan dan penghuni bangunan. Diantara manfaat tersebut adalah dapat menghemat penggunaan energi bangunan. Hal ini merupakan konsekuensi langsung yang didapatkan akibat berkurangnya penggunaan energi listrik. Penggunaan energi listrik bisa dihemat sampai dengan 40 persen, termasuk pada bangunan sekolah, jika mengintegrasikan pencahayaan alami yang baik dan benar (Lechner, 2007). Tentunya, hal ini sangat berguna sebagai usaha dan langkah penting untuk konservasi energi pada bangunan.

Selain manfaat energi tersebut, pencahayaan alami juga berdampak langsung kepada pengguna bangunan. Pada bangunan sekolah dasar desain pencahayaan alami yang baik berpengaruh pada performa dan kesehatan siswa. Lechner (2007) menyebutkan pencahayaan alami pada pagi hari dapat menekan produksi melatonin yang menimbulkan rasa kantuk. Pada sekolah dasar kondisi ini dapat meningkatkan minat dan performa belajar dari siswa. Lebih jauh, Mediastika (2013) dan Boubekri (2008) menjelaskan beberapa manfaat pencahayaan alami bagi kesehatan diantaranya membantu produksi vitamin $\mathrm{D}$, meningkatkan kekebalan tubuh, meningkatkan sirkulasi darah, memperbaiki mood dan juga dapat mengurangi depresi. Manfaat seperti ini berhubungan langsung dengan peningkatan performa dari siswa jika pencahayaan alami yang baik diperhatikan pada bangunan terutama sekolah dasar.

Beberapa studi pada sekolah dasar telah menunjukkan peran penting pencahayaan alami. Diantaranya adalah studi yang dilakukan di Swedia pada 90 sekolah dasar menunjukkan bahwa pencahayaan alami dapat memperbaiki konsentrasi, hal ini disebabkan oleh perubahan pola hormon pada siswa. Preferensi positif terhadap cahaya alami juga ditunjukkan pada studi sekolah dasar di Amerika Serikat. Pada penelitian tersebut menunjukkan performa siswa meningkat $20 \%$ lebih baik pada tes matematika dan 26\% lebih capat pada tes membaca (Boubekri, 2008). Tren serupa juga ditunjukkan pada studi yang dilakukan oleh Heschong, Wright, \& Okura (2000) pada sekolah dasar di California, Amerika Serikat. Studi tersebut cukup memperkuat alasan pentingnya pencahayaan alami pada sekolah dasar. Lebih lanjut, pentingnya pencahayaan alami pada sekolah dasar karena berperan untuk mencetak generasi masa depan yang lebih baik.

Dari hasil investigasi literatur, didapatkan bahwa data pencahayaan alami pada sekolah dasar di Kota Lhokseumawe tidak ditemukan. Padahal, seperti telah dijelaskan pada beberapa studi diatas pencahayaan alami tidak hanya baik bagi energi tapi juga baik bagi performa dan kesehatan siswa. Keberadaan data pencahayaan alami ini penting terutama untuk memperbaiki dan meningkatkan kualitas desain sekolah dasar yang ramah pencahayaan alami sehingga dapat membantu siswa meningkatkan kondisi dan performa belajar. 
Untuk dapat melakukan dan mendapatkan data pencahayaan alami dengan efektif dan efisien, studi ini mengintegrasikan metode simulasi komputasional dengan Climate Based Daylight Modeling (CBDM). Dengan CBDM memungkinkan untuk menguji kondisi pencahayaan alami yang lebih akurat dan spesifik ke lokasi tertentu. Hal ini disebabkan CBDM menggunakan data cuaca lokasi tertentu untuk simulasi. Dalam CBDM ada beberapa metrik yang dapat dilakukan untuk menilai data pencahayaan alami seperti Daylight Autonomy (DA) dan Useful Daylight Illuminance (UDI). Pada penilaian dengan metrik DA, kita hanya dapat menentukan batas bawah saja untuk kondisi pencahayaan alami. Kualitas pencahayaan alami dianggap memenuhi jika sudah berada diatas batas atas. Situasi ini dinilai problematik karena potensi silau atau panas berlebihan akibat cahaya matahari yang masuk kedalam ruangan tidak dapat diprediksi. Metrik UDI menawarkan tiga kondisi yaitu batas bawah, kondisi memenuhi, dan kondisi batas atas atau overbright (Nabil \& Mardaljevic, 2005). Metrik UDI ini lebih baik dibandingkan dengan DA karena kemampuan membuat kategori seperti telah dijelaskan sebelumnya.

Studi ini menggunakan metrik UDI untuk menilai kualitas pencahayaan alami pada ruang belajar Sekolah Dasar Negeri 2 dan 6 di Kecamatan Banda Sakti, Lhokseumawe yang beriklim tropis. Kondisi tropis ini memberikan potensi cahaya alami yang banyak untuk dapat digunakan dan dimanfaatkan sebagai sumber pencahayaan alami pada ruangan. Sekolah dasar tersebut dipilih untuk beberapa alasan. Pertama, sekolah tersebut berada pada lokasi urban Kota Lhokseumawe yang paling padat. Kedua, sekolah tersebut terdiri lebih dua lantai dan luas lantai paling besar diantara sekolah dasar lainnya yang bertingkat. Ketiga, ruangan kelas pada sekolah tersebut memiliki empat orientasi berbeda. Terakhir, ada dua jenis tipe bukaan sehingga memungkinkan evaluasi dan membandingkan efektifitas jenis bukaan yang digunakan. Dengan beberapa alasan tersebut maka Sekolah Dasar Negeri 2 dan 6 dapat terpenuhi untuk dijadikan objek kajian pada studi ini. Selanjutnya, kedua sekolah ini berada pada lokasi yang sama yaitu di Jalan Sultanah Nahrasiyah, Kampung Jawa Lama, Kota Lhokseumawe. Kedua sekolah tersebut juga tidak dibatasi oleh pagar, sehingga terlihat seperti satu sekolah.

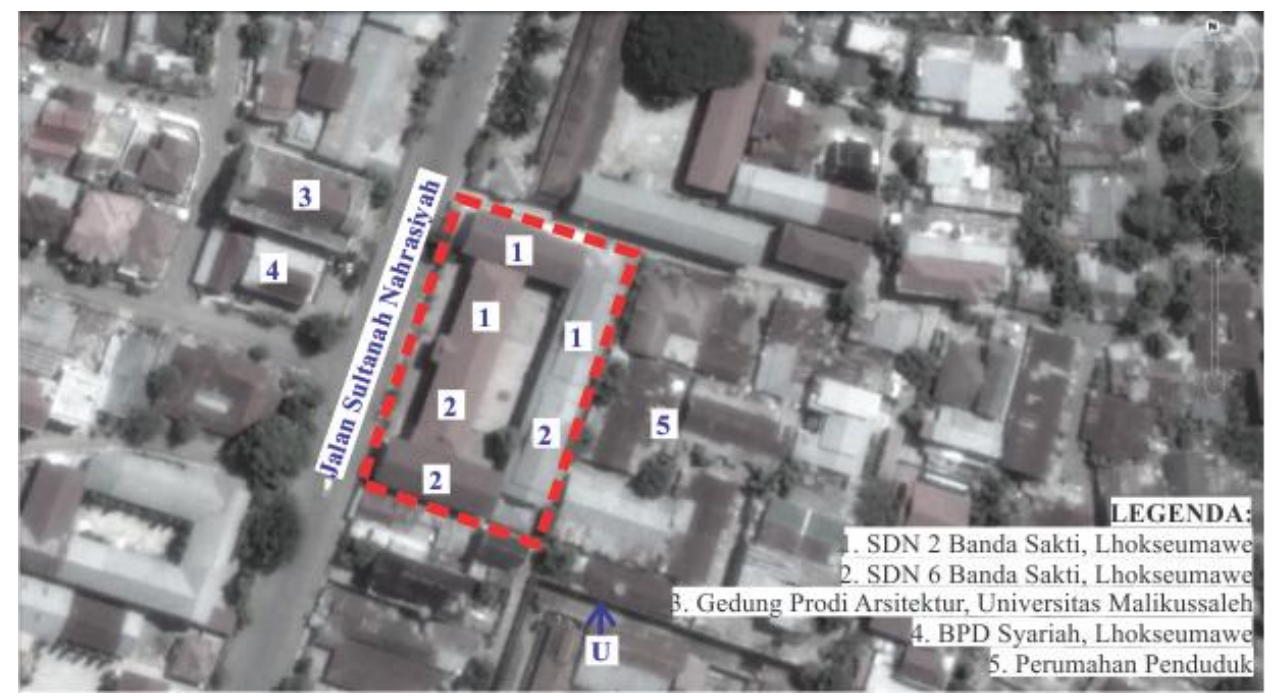

Gambar 1. Lokasi SDN 2 \& 6 Banda Sakti Lhokseumawe

Sumber: Penulis, 2019

\section{Kajian Pustaka}

Ada beberapa studi, namun sangat terbatas, yang telah dilakukan untuk investigasi pencahayaan alami pada bangunan sekolah dasar di Indonesia. Idrus, Hamzah, \& Mulyadi (2016) melakukan penelitian pada tiga sampel sekolah dasar yang ada di Kota Makasar. Penelitian tersebut dilakukan dengan metode kuantitatif dengan pengukuran langsung pada satu hari tertentu disetiap 
sekolah yang menjadi objek studi. Pengukuran data juga dilakukan setengah hari saja. Pada penelitian ini pengolahan data hasil pengukuran menggunakan piranti lunak SPSS. Hasil menunjukkan $87.9 \%$ ruang kelas sekolah yang diuji berada dibawah standar yang ditetapkan. Tentunya pengukuran yang dilakukan pada satu waktu ini tidak dapat menggambarkan profil pencahayaan tahunan yang lebih akurat untuk diambil kesimpulannya. Hal ini menunjukkan keterbatasan dari penelitian yang melakukan pengukuran fisik yang memakan waktu lebih lama untuk hasil yang lebih baik.

Selanjutnya, Wibowo, Kindangen, \& Sangkertadi (2017) melakukan studi kualitas cahaya pada sekolah dasar yang ada di Kota Manado. Pada penelitian tersebut simulasi statis menggunakan metrik Daylight Factor (DF) dilakukan. Penelitian ini menunjukkan bahwa dari dua sekolah dasar yang terpilih kondisi kekurangan cahaya alami. Dari hasil studi mereka perubahan konteks disekitar sekolah menjadi padat adalah salah satu faktor penting penyebab berkurangnya cahaya alami kedalam ruangan. Simulasi dengan DF menganggap semua kondisi langit sama dan mengabaikan keberadaan kondisi matahari. Sehingga, pada simulasi DF orientasi tidak dianggap penting. Hal ini merupakan kekurangan yang tidak bisa mewakili daerah spesifik ke lokasi penelitian menggunakan metrik DF.

Dari hasil kajian diatas, bahwa tren penelitian pencahayaan alami pada sekolah dasar masih langka terutama di Indonesia. Seharusnya hal tersebut menjadi fokus mengingat pentingnya kontribusi pencahayaan alami baik untuk efisiensi energi bagi bangunan maupun performa dan kesehatan bagi siswa. Selain itu, penelitian simulasi dengan Climate Based Daylight Modeling, secara spesifik simulasi Useful Daylight Illuminance (UDI) tidak ditemukan pada studi-studi terdahulu. Jadi dari alasan diatas maka studi ini melakukan investigasi UDI pada sekolah dasar di Kota Lhokseumawe. Selanjutnya, dengan adanya studi ini diharapkan tren untuk melakukan investigasi UDI pada sekolah dasar di Indonesia dapat ditingkatkan, sehingga data pencahayaan alami pada sekolah dasar dapat diperoleh untuk desain sekolah lebih baik.

Perlu menjadi perhatian bahwa dalam CBDM, orientasi merupakan hal yang berkonstribusi penting terhadap pencahayaan alami didalam ruangan. Hal ini senada dengan yang dikemukakan oleh Anderson (2014). Lebih jauh, orientasi merupakan salah satu strategi penting dalam mencapai pencahayaan alami yang baik (Lechner, 2007; Mediastika, 2013). Sebagai contoh , studi sebelumnya tentang rotasi yang berbeda bilah horizontal disetiap orientasi menentukan tingkat penerimaan pencahayaan alami yang baik telah dibahas oleh Atthaillah, Bakhtiar, \& Badriana (2019). Faktor penting lainnya yang menjadi pertimbangan dalam mendapatkan iluminasi cahaya alami yang baik adalah window wall ratio (WWR). WWR merupakan perbandingan luas bukaan dengan luas bidang dinding pada bangunan. Semakin tinggi nilai WWR maka bukaan pada suatu bangunan akan semakin besar. Mediastika (2013) mengatakan untuk daerah tropis seperti Indonesia bukaan atau WWR semestinya dioptimalkan pada orientasi utara dan selatan. Hal ini dimaksudkan untuk menghindari paparan langsung dari sinar matahari sehingga bisa mereduksi panas yang diterima dalam bangunan. Namun, jika hal tersebut tidak mungkin, maka, bukaan pada orientasi yang dihindari seperti sisi barat dipadukan dengan desain kulit bangunan bilah horizontal seperti disarankan pada studi Atthaillah et al. (2019), Atthaillah, Iqbal, \& Situmeang (2017), Atthaillah, Wijayanti, \& Hassan (2018).

\section{Metode}

\section{Jenis dan Metode}

Penelitian ini mengintegrasikan metode simulasi komputasional. Simulasi dapat diartikan sebagai usaha untuk menciptakan kondisi replikasi dari keadaan sebenarnya (Groat \& Wang, 2013). Sedangkan komputasional dapat didefinisikan sebagai usaha kalkulasi termasuk didalamnya modeling dan simulasi dengan bantuan komputer. Jadi, disini simulasi komputasional dapat diartikan proses perhitungan kebutuhan cahaya dengan memodelkan objek sesuai dengan keadaan sebenarnya 
berdasarkan data lapangan dengan bantuan komputer. Pemodelan pencahayaan alami yang dimaksud adalah Climate Based Daylight Modeling (CBDM).

Seperti telah dijelaskan sebelumnya CBDM diintegrasikan pada studi ini. Anderson (2014) mengatakan CBDM lebih akurat dalam mendeskripsikan kondisi pencahayaan alami pada ruangan. Simulasi CBDM dengan metrik Useful Daylight Illuminance (UDI) digunakan pada penelitian ini. UDI merupakan metrik perhitungan pencahayaan alami yang relatif kontemporer yang pertama sekali diperkenalkan oleh Nabil \& Mardaljevic (2005). Sebelum UDI, CBDM dapat dilakukan dengan Daylight Autonomy (DA), namun, seperti telah dijelaskan sebelumnya DA tidak mampu memprediksi potensi ketidaknyaman visual dan termal karena dalam DA hanya menentukan batas iluminasi bawah saja. UDI mengukur seberapa sering iluminasi cahaya matahari dalam setahun, pada batasan yang ditentukan diterima. Lebih jauh, mereka menyatakan Daylight Factor (DF) tidak realistik untuk merepresentasikan kondisi cahaya alami (Nabil \& Mardaljevic, 2005).

Dalam UDI terdapat beberapa kriteria iluminasi pencahayaan alami yang diukur, diantaranya adalah kondisi <100 Lux, merupakan area yang tidak menerima cahaya matahari yang cukup atau area yang redup. Selanjutnya adalah kondisi yang diharapkan atau memenuhi iluminasi pencahayaan alami yaitu antara 100-2000 Lux. Terakhir adalah illuminasi >2000 Lux yaitu kondisi pencahayaan alami yang berpotensi menyebabkan ketidaknyamanan visual dan termal.

\section{Metode Pengumpulan dan Analisa Data}

Proses pengumpulan data dilakukan dalam beberapa tahap, pertama, melakukan survey dan melakukan pengukuran objek penelitian dengan menggunakan meteran dan laser meter. Pada tahap ini melibatkan pencatatan data pengukuran dalam bentuk sketsa dan tabulasi. Pengukuran juga dilakukan terhadap konteks yang berada didalam maupun sekeliling objek penelitian. Ukuran dan jenis kaca bukaan berpengaruh sangat signifikan pada keakuratan hasil simulasi, untuk itu data ini wajib dipastikan dengan benar dan sesuai dengan kondisi aslinya. Pencatatan juga dilakukan terhadap objek-objek interior yang dapat menghambat masuknya cahaya alami kedalam ruangan, misalnya, jendela memakai gorden atau blinds. Selain itu, orientasi bangunan juga harus benar-benar diperhatikan karena UDI mempertimbangkan orientasi untuk hasil simulasi.

Kedua, melakukan proses pemodelan objek penelitian dengan aplikasi Rhinoceros Educational versi 6. Pemodelan dilakukan terhadap bangunan yang menjadi kajian dan konteks sesuai data lapangan. Selain sebagai antar muka, pemodelan di Rhinoceros berfungsi sebagai media untuk visualisasi hasil simulasi UDI. Ketiga, menginput model Rhinoceros kedalam Grasshopper versi 1. Input ini diproses ke algoritma dibuat dengan Ladybug versi 0.0.66 dan Honeybee 0.0.63 yang merupakan plug-ins Grasshopper3D. Algoritma dapat didefinisikan sebagai sekumpulan instruksi atau aturan yang memiliki prosedur tertentu untuk kalkulasi, memproses data dan melakukan tugastugas tertentu (Khabazi, 2012; Tedeschi, 2014). Pada tahap ini melibatkan pembacaan data cuaca melalui algoritma Ladybug, data cuaca harus dalam format .EPW (Energyplus Weather Format). Data cuaca untuk kota Lhokseumawe dapat diperoleh secara komersial dari ASHRAE IWEC2 Weather Files (n.d.). Pada tahap ketiga ini juga melibatkan implementasi properti material kaca yang sesuai kondisi eksisting. 


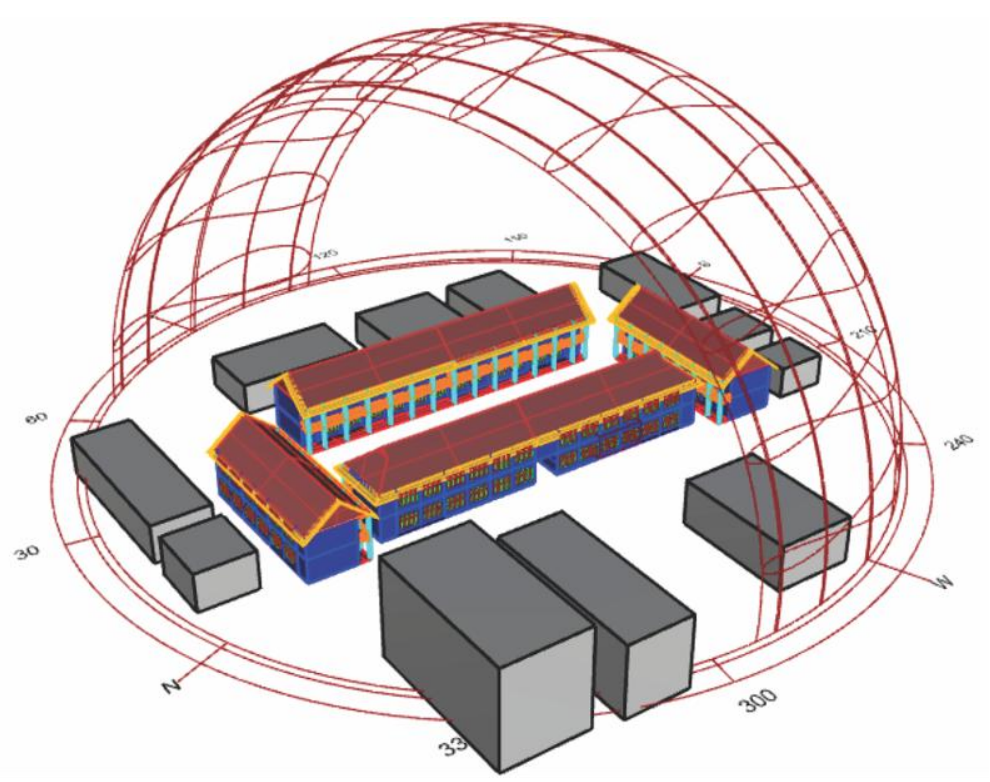

Gambar 2. Pemodelan Objek Penelitian Dan Diagram Matahari Sesuai Konteks Dengan Diagram Matahari

Sumber: Penulis, 2019

Keempat, proses simulasi yang terhubung dengan engine simulasi secara otomatis melalui algoritma Honeybee yaitu Daysim. Terakhir adalah pembacaan hasil simulasi yang didapatkan dalam bentuk visual dan numerik. Dengan menggunakan plug-ins Honeybee nilai UDI dapat diatur sesuai dengan Standar Nasional Indonesia untuk kebutuhan cahaya pada ruang kelas sekolah dasar. Untuk ruang kelas iluminasi yang diinginkan berdasarkan SNI 03-6197 (2000) adalah 250 Lux. Dari standar tersebut diperoleh bahwa batas maksimal illuminasi untuk bangunan sekolah atau lembaga pendidikan adalah 750 Lux. Sehingga, pada penelitian ini nilai UDI terpenuhi diganti dari 100-2000 Lux menjadi 250-750 Lux.

\section{Data Teknis Objek Penelitian}

Seperti telah dijelaskan sebelumnya penelitian ini hanya melihat performa pencahayaan alami pada ruang belajar. Bangunan-bangunan atau objek yang berkontribusi menjadi penghalang cahaya matahari dimodelkan sesuai dengan kondisi eksisting. Untuk SDN 2 dan 6 Banda Sakti, Lhokseumawe memiliki ukuran ruang kelas 7,7 meter x 7,7 meter dengan jumlah ruang kelas yang dievaluasi 36 ruang dengan tinggi seluruh ruang kelas adalah 3,7 meter. Kedua sekolah memiliki konstruksi utama beton bertulang dan material bangunan adalah dinding bata dengan finishing plaster serta kaca jendela transparan. Selanjutnya, ada dua kondisi Window Wall Ratio (WWR) untuk per ruang kelas pada objek studi. Pertama, R.0, R.1, R.2, R.8, R.9 R.10 (lantai 1) dan R.5, R.6, R.7, R.13, R.14, R.15 (lantai 2) memiliki nilai WWR 9,07 persen. Sementara raungan belajar lainnya memiliki nilai WWR 10,32 persen. Pada penelitian ini penomoran ruang kelas ditentukan secara otomatis oleh algoritma Grasshopper. Nomor-nomor ruang ini digunakan untuk tujuan identifikasi, analisa dan pembahasan pada artikel ini. Selanjutnya, ruangan disimulasikan pada kondisi kosong tanpa meja dan kursi belajar. Hal ini dilakukan untuk melihat efektifitas cahaya alami pada ruang kelas berdasarkan desain. Pada gambar layout SDN 2 dan 6 Banda Sakti berikut ruang yang dibeli nomor atau label R.3, R.11, R.20, R.27, R.36, R.43 (lantai 1) dan R.4, R.12, R.19, R.28, R.35, R.44 (lantai 2) merupakan ruang tangga yang tidak menjadi fokus pada penelitian ini. Layout dan penamaan keseluruhan ruangan kelas yang distudi adalah seperti terlihat pada gambar berikut untuk setiap lantainya. 


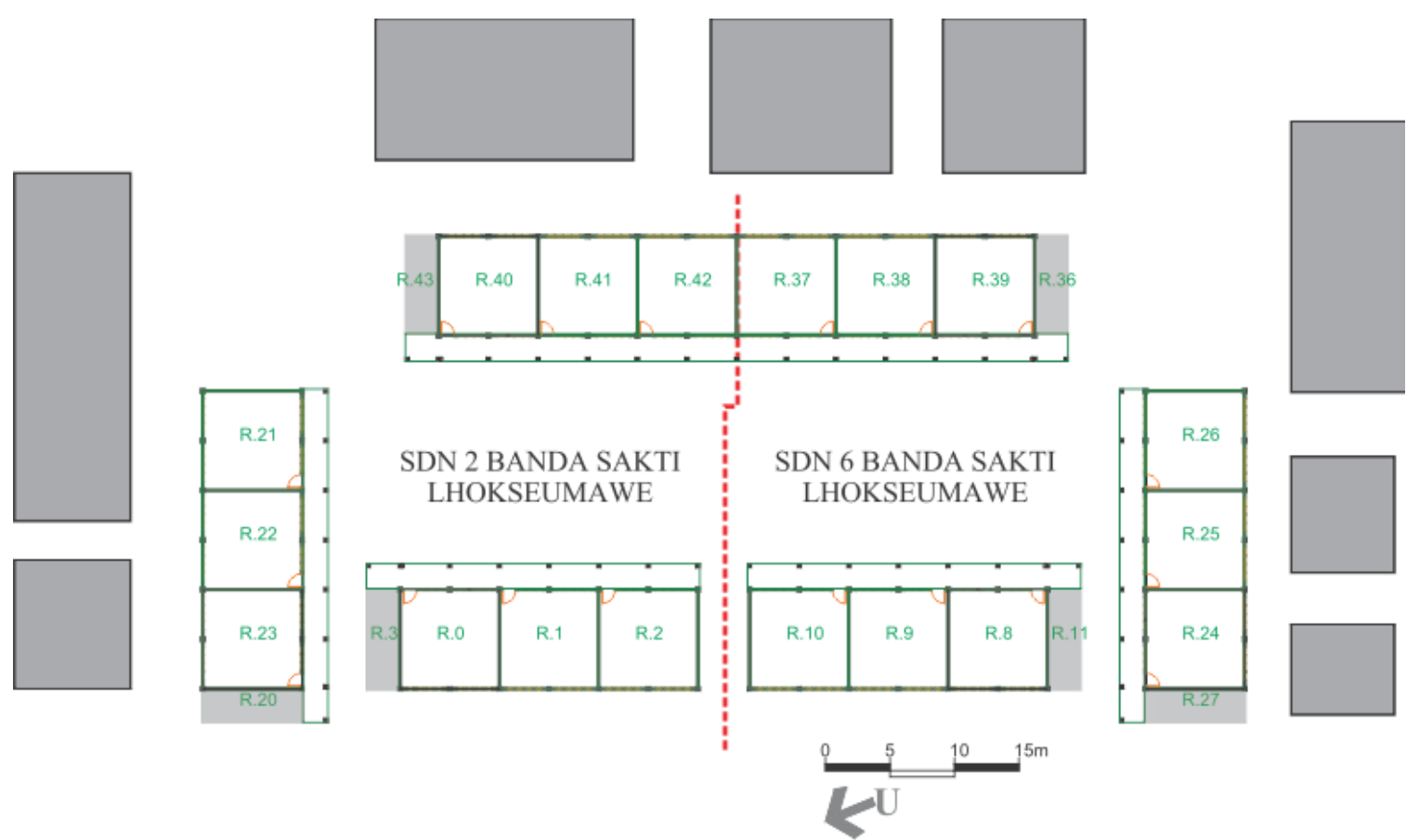

Gambar 3. Layout SDN 2 Dan 6 Banda Sakti Lantai 1

Sumber: Penulis, 2019

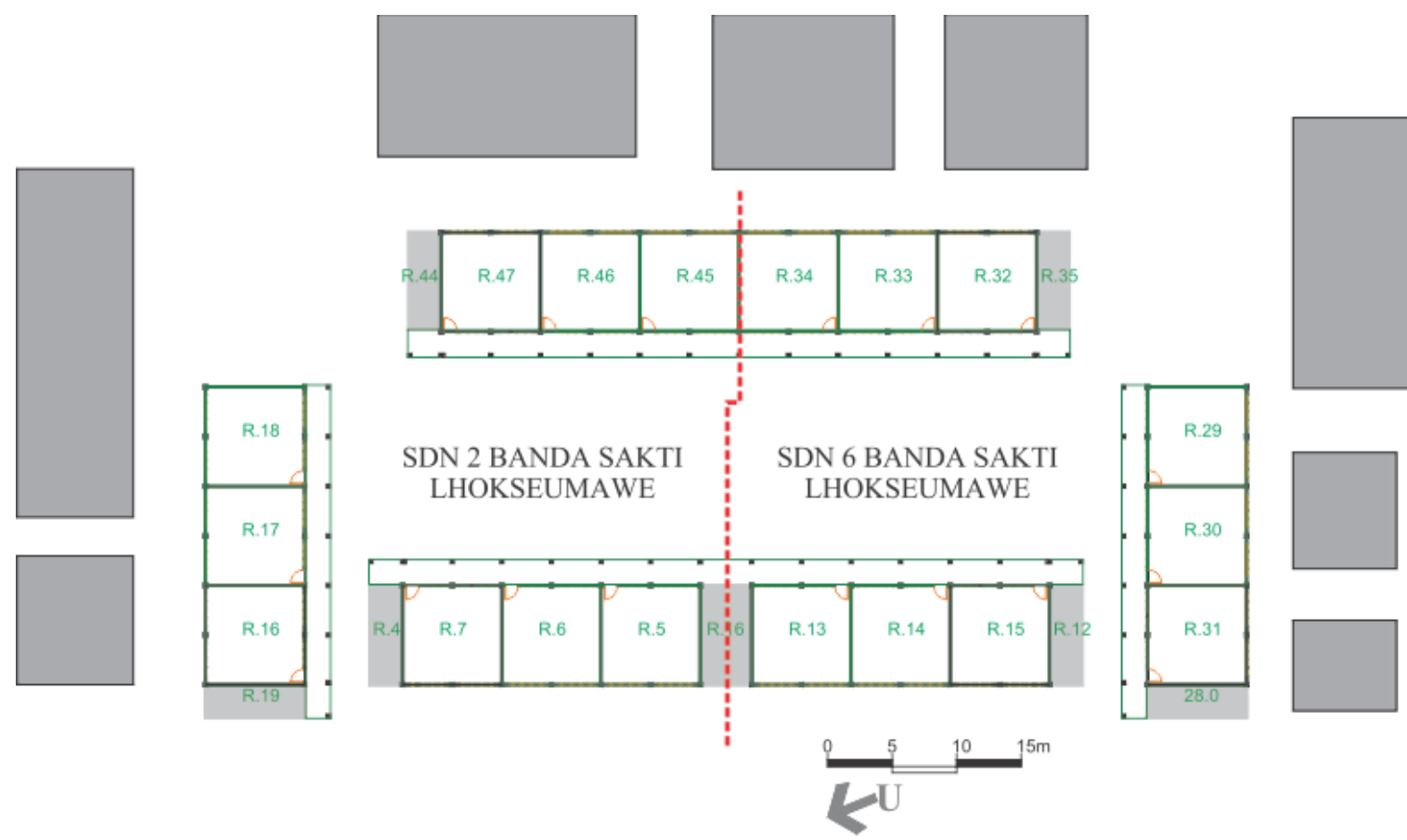

Gambar 4. Layout SDN 2 Dan 6 Banda Sakti Lantai 2

Sumber: Penulis, 2019 

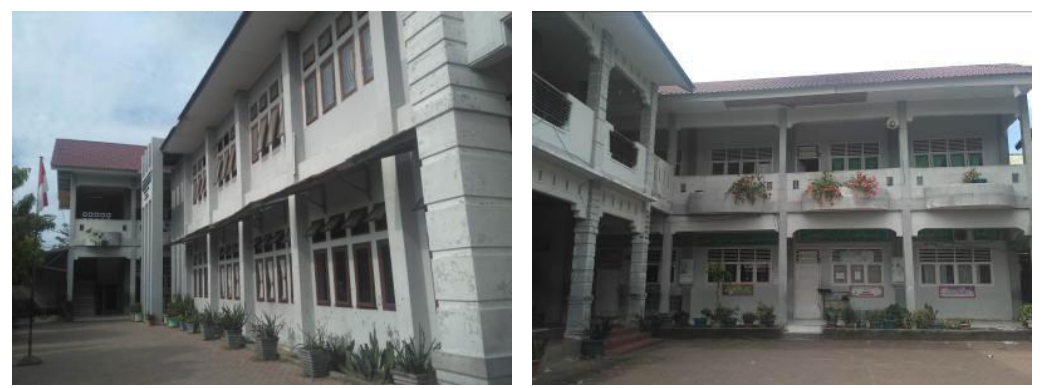

Gambar 5. Ruang Kelas Dengan WWR 9,07\% (Kiri) Dan WWR 10,32\% (Kanan)

Sumber: Penulis, 2019

\section{Penentuan Titik Ukur (TU)}

Titik ukur pada penelitian ini ditentukan pada elevasi 0,75 meter dengan jarak antar titik ukur 1 meter. Titik ukur tersebut diberi label dari TU.0-TU.48 untuk setiap ruang kelas. Pelabelan TU ini dimulai dari pintu yang diteruskan kearah dalam. Kemudian setelah batas kedalaman ruang tercapai maka kolom selanjutnya dimulai penomoran lagi. Pola penentuan TU pada setiap kelas mengikuti penjelasan diatas. Berikut salah satu contoh ruang belajar dan penempatan titik ukur yang dilakukan pada ruang belajar R.6.

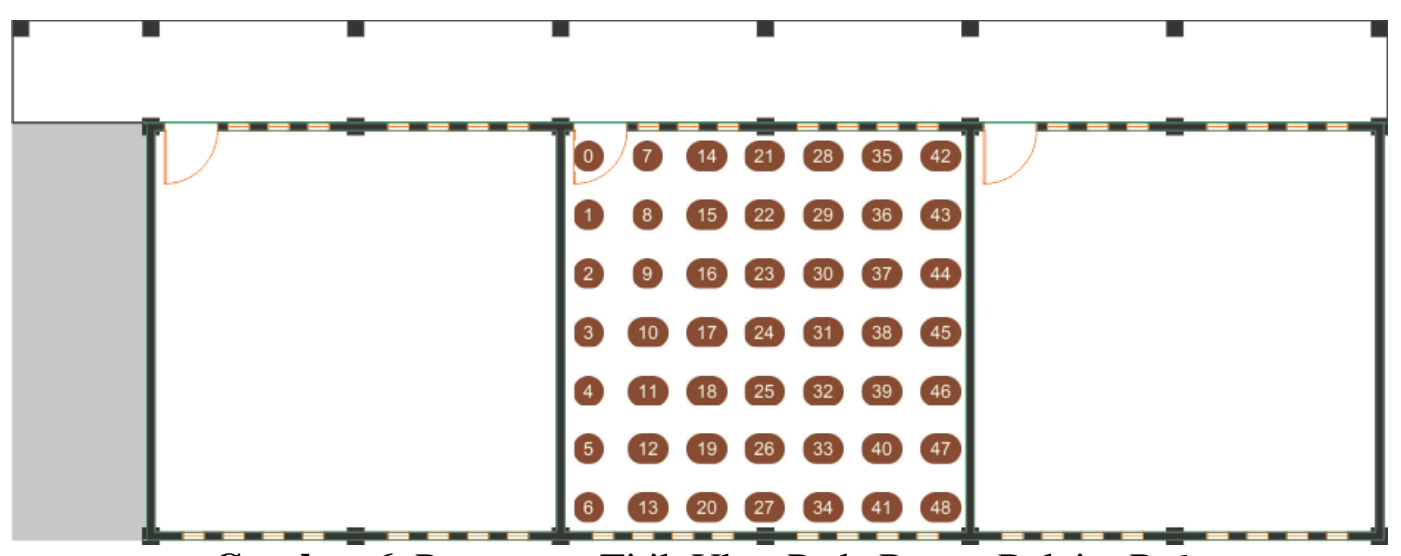

Gambar 6. Penentuan Titik Ukur Pada Ruang Belajar R.6

Sumber: Penulis, 2019

\section{Skala Penilaian Hasil}

Penelitian ini menggunakan sistem skala 5 tingkat untuk menentukan kategorisasi performa pencahayaan alami pada ruang belajar. Kategori performa tersebut ditentukan berdasarkan rata-rata TU perkelas untuk nilai UDI 250-750 Lux. Rentang UDI 250-750 Lux ditentukan melalui persentasi seberapa sering nilai iluminasi dalam batas terpenuhi dicapai dalam kurun waktu setahun yaitu 0 100\%. Dengan rentang tersebut maka jarak kelas (interval) untuk skala 5 dapat ditentukan menjadi 20 (dua puluh) untuk setiap kategorinya. Kategori penilaian yang dimaksud dapat dilihat pada tabel berikut. 
Tabel 1. Skala Penilaian

\begin{tabular}{|l|l|}
\hline Kategori & \multicolumn{1}{|c|}{$\begin{array}{c}\text { UDI Rata-rata } \\
(\boldsymbol{\%})\end{array}$} \\
\hline Sangat Baik & $81-100$ \\
\hline Baik & $61-80$ \\
\hline Cukup & $41-60$ \\
\hline Kurang & $21-40$ \\
\hline Sangat Kurang & $0-20$ \\
\multicolumn{2}{|c|}{ Sumber: Penulis, 2019}
\end{tabular}

\section{Hasil dan Pembahasan}

Pada studi ini ada empat jenis orientasi yang digunakan untuk pembahasan hasil simulasi. Orientasi pertama adalah ruang-ruang yang sisi depannya menghadap ke arah Timur +30 derajat. Selanjutnya orientasi ini disebut $\mathrm{T}+30$. Penambahan sudut orientasi sebesar 30 derajat merupakan arah hadap relatif dari setiap ruang yang tidak tepat ke arah orientasi utama. Berikutnya, orientasi kedua, ketiga dan keempat berlaku hal yang sama yaitu pergeseran 30 derajat dari mata angin utama. Penyebutan untuk orientasi kedua Barat $+30(\mathrm{~B}+30)$, orientasi ketiga Selatan $+30(\mathrm{~S}+30)$ dan terakhir Utara $+30(\mathrm{U}+30)$. Penyajian berdasarkan orientasi ini dilakukan mengingat pentingnya peran orientasi dalam penerimaan iluminasi seperti dijelaskan oleh Lechner (2007) dan Mediastika (2013).

Sementara, hasil simulasi dibagi menjadi ruang-ruang pada lantai satu dan lantai dua seluruh orientasi dalam bentuk gradasi warna gelap terang pada setiap titik ukur (TU) dan grafik rata-rata UDI 250-750 Lux (cahaya optimal) untuk setiap ruang belajar. Adapun kondisi gelap pada gambar gradasi gelap terang menunjukkan kondisi tidak terpenuhi UDI 250-750 Lux. Ini tidak berarti bahwa secara literal kondisi gelap merupakan area gelap pada ruangan, tetapi kondisi tidak terpenuhi tersebut bisa disebabkan oleh kekurangan cahaya yakni UDI < 250 Lux atau kelebihan cahaya dengan kondisi UDI>750 Lux.

Pertama, hasil simulasi visual untuk seluruh kelas pada lantai satu dapat dilihat pada gambar 7. Sementara hasil simulasi berupa nilai rata-rata UDI 250-750 Lux dalam bentuk grafik numerik dapat dilihat pada gambar 8. Pada lantai satu kondisi rata-rata UDI 250-750 Lux terendah berada pada R.23 dan R.24 berturut-turut 22,36\% (orientasi S+30) dan 22,47\% (orientasi U+30). Dalam skala penilaian ruangan belajar ini masuk dalam kategori kurang $(\mathrm{K})$. Kondisi ini disebabkan oleh penghalang cahaya matahari yang berupa konteks dan juga tata layout sekolah yang menyebabkan ruangan-ruangan tersebut terhalangi oleh bangunan pada orientasi $\mathrm{T}+30$. Kontribusi konteks terhadap penerimaan cahaya alami tidak optimal senada dengan yang dikatakan oleh Wibowo et al.(2017). Selanjutnya, ruangan dengan kategori K lainnya terletak pada orientasi S+30 adalah R.21 dan R.22 dengan kondisi cahaya alami rata-rata terpenuhi 40,04\% dan 38,08\%. Ruang kategori K lainnya juga terdapat pada orientasi U+30 yaitu R.25 (35,86\%). Terakhir, pada lantai satu yang masuk kategori $\mathrm{K}$ adalah ruang R.37 yang terletak di orientasi $\mathrm{B}+30$ dengan persentase rata-rata $37,43 \%$. Dengan demikian ada enam ruangan dengan kategori K terletak pada lantai satu. Penyebab utama tereduksi cahaya pada ruangan tersebut adalah kondisi konteks yang padat dan menghalangi cahaya matahari masuk kedalam ruangan. Selain itu, kondisi WWR 10,32\% yang identik untuk semua ruangan dengan kategori $\mathrm{K}$ pada lantai satu juga berkontribusi terhadap pemasalahan penerimaan pencahayaan alami yang baik.

Dari gambar 8, jika dibandingkan seluruh ruangan untuk orientasi terbaik pada lantai satu dengan konteks dan WWR eksisting maka orientasi $\mathrm{T}+30$ adalah yang terbaik. Hal ini terlihat dari kondisi rata-rata UDI terpenuhi dengan nilai $44,90 \%$. Sementara orientasi $\mathrm{B}+30, \mathrm{~S}+30$ dan U+30 merupakan urutan terbaik berikutnya pada lantai satu dengan nilai rata-rata berturut-turut $42,45 \%$, $33,49 \%$ dan 38,88\%. Ruangan dengan orientasi $\mathrm{T}+30$, dengan kondisi tidak ada bangunan konteks 
dan penghalang cahaya lainnya, juga menunjukkan bahwa desain bukaan (WWR 9,07\%) tidak bisa dikategorikan baik. Hal ini ditunjukkan pada gambar 8 bahwa keenam ruangan yang berada pada orientasi tersebut tidak ada nilai UDI 250-750 Lux rata-rata diatas 61\%. Artinya, desain bukaan untuk ruang belajar ini harus dipertimbangkan ulang.

Berikutnya, kondisi tidak terpenuhi UDI 250-750 Lux pada ruangan belajar di lantai 1 (satu) dengan berbagai orientasi disebabkan oleh ketidakcukupan (UDI <250 Lux) dan kelebihan cahaya (UDI >750 Lux). Komparasi nilai UDI $<250$ Lux dan UDI >750 Lux pada lantai satu untuk berbagai orientasi ruangan ditunjukkan pada gambar 9. Pada ilustrasi tersebut terlihat bahwa cahaya optimal (UDI 250-750 Lux) tidak dapat dicapai disebabkan oleh kondisi gelap dan terang yang berlebihan. Namun, untuk setiap orientasi jika dirata-ratakan maka $\mathrm{T}+30$ dan $\mathrm{B}+30$ lebih banyak dipengaruhi oleh kelebihan cahaya (UDI >750 Lux) yaitu 29,30\% ( +30$)$ dan 33,55\% (B+30). Sementara, untuk kondisi gelap (UDI <250 Lux) pada orientasi ini berkonstribusi $25,80 \%(\mathrm{~T}+30)$ dan $24 \%(\mathrm{~B}+30)$ pada ruangan.

Selanjutnya, pada lantai 1(satu) orientasi S+30 dan U+30 lebih didominasi oleh kondisi gelap dan jika dirata-ratakan kontribusinya secara berturut-turut $42,34 \%(\mathrm{~S}+30)$ dan $42,31 \%(\mathrm{U}+30)$. Kondisi UDI $>750$ Lux jika dirata-ratakan pada orientasi ini $24,17 \%(\mathrm{~S}+30)$ dan $20,82 \%(\mathrm{U}+30)$. Kondisi gelap didominasi pada ruangan-ruangan tersebut disebabkan oleh penghalang cahaya matahari. Lebih jauh, pada orientasi $\mathrm{T}+30$ dan $\mathrm{B}+30$ kondisi cahaya tidak optimal secara dominan disebabkan oleh kelebihan penerimaan cahaya alami (UDI>750) yaitu dengan rata-rata 29,30\% $(\mathrm{T}+30)$ dan 33,55 $(\mathrm{B}+30)$. Sementara, rata-rata persentase UDI $<250$ pada orientasi ini adalah $25,80 \%$ $(\mathrm{T}+30)$ dan 24,00\% $(\mathrm{B}+30)$. Gambar 9 menjelaskan komparasi lebih rinci tentang situasi UDI $<250$ Lux dan UDI>750 Lux untuk setiap ruangan yang berada pada lantai satu.

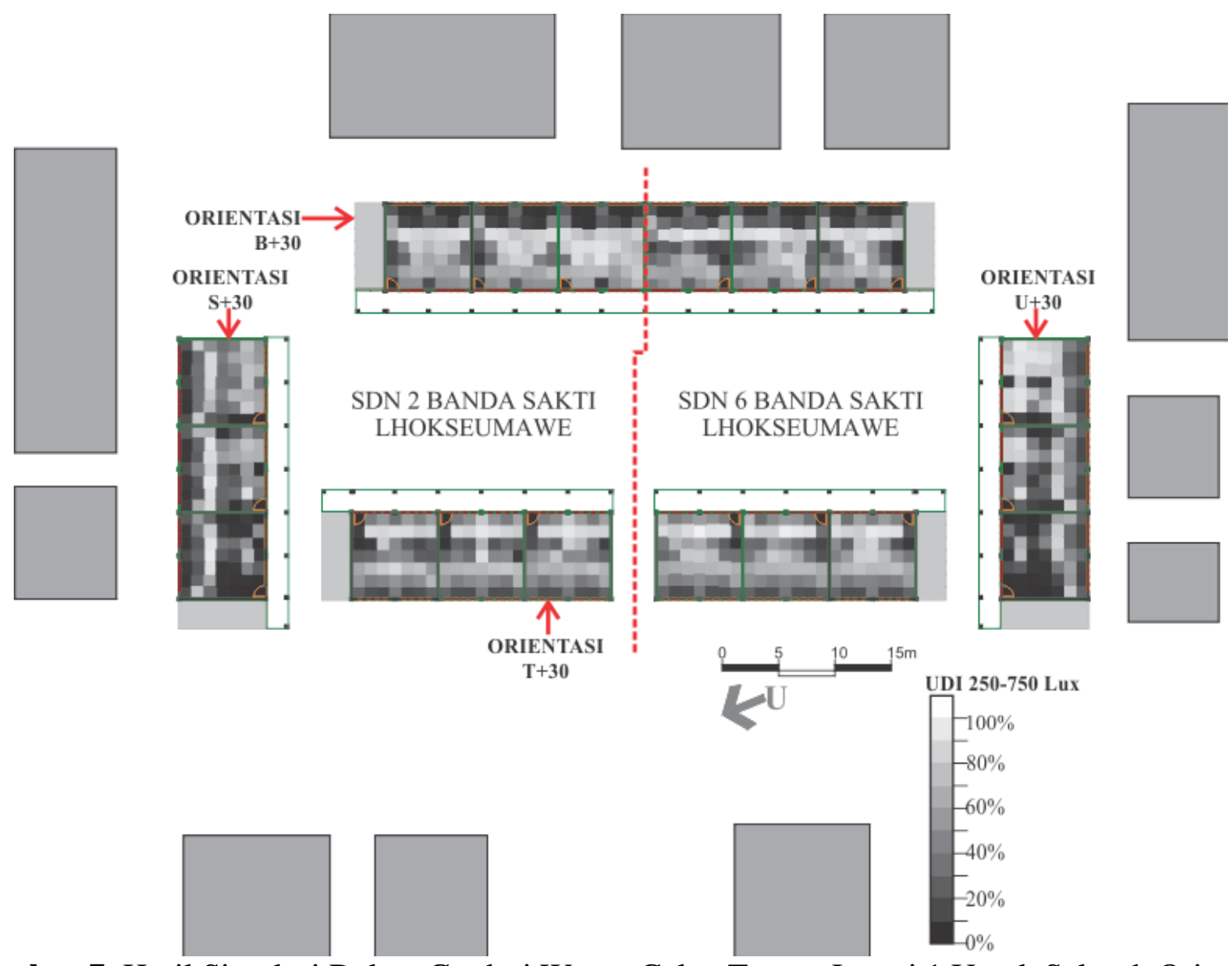

Gambar 7. Hasil Simulasi Dalam Gradasi Warna Gelap Terang Lantai 1 Untuk Seluruh Orientasi Sumber: Penulis, 2019 

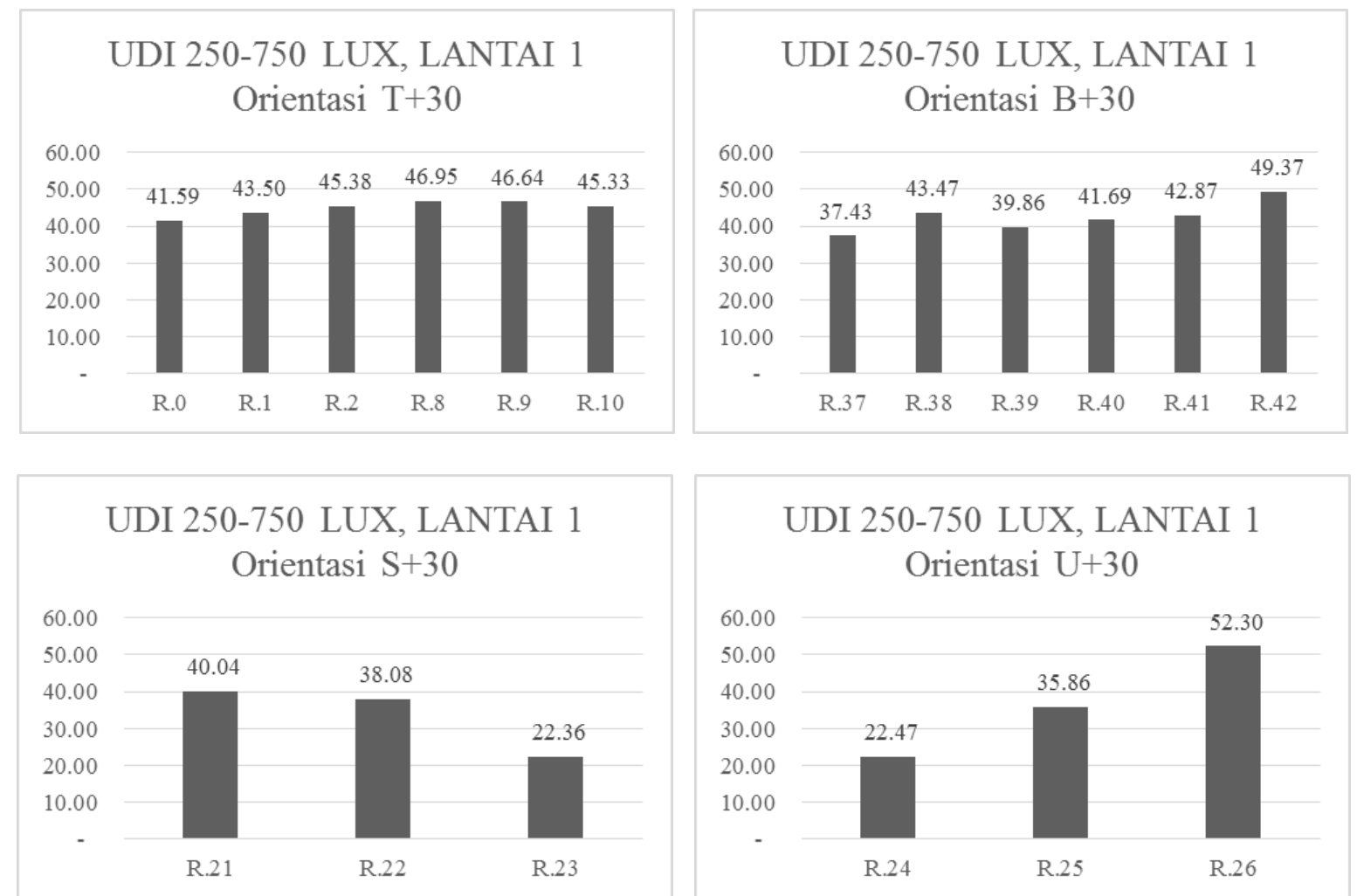

Gambar 8. Grafik Hasil Simulasi Rata-Rata UDI 250-750 Lux Pada Lantai 1 Semua Orientasi Sumber: Penulis, 2019
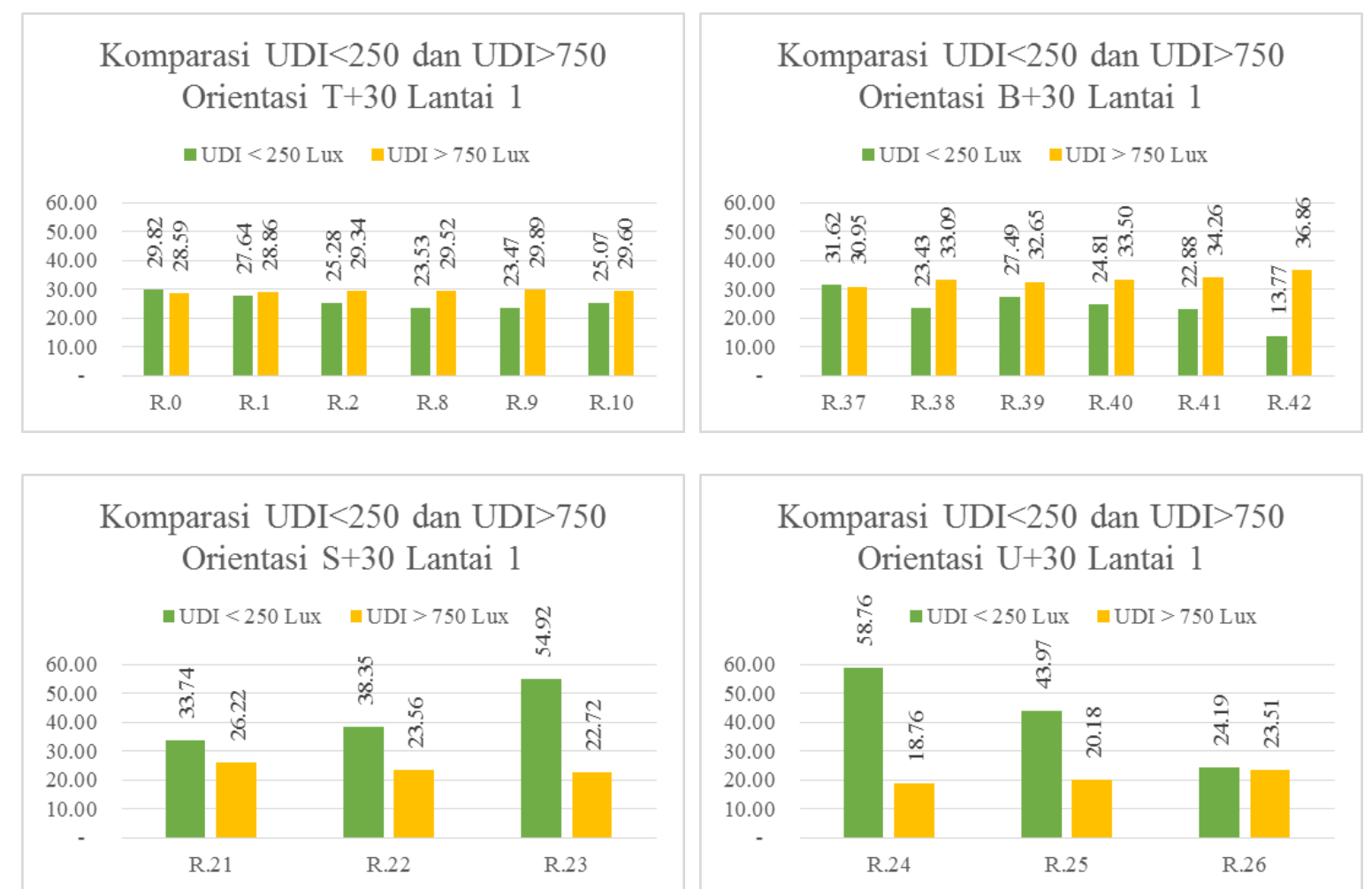

Gambar 9. Grafik Komparasi UDI<250 Lux Dan UDI>750 Lux Pada Lantai 1 Semua Orientasi Sumber: Penulis, 2019 
Untuk lantai 2 (dua) kondisi UDI 250-750 Lux terdapat sedikit perbedaan dengan yang terjadi pada lantai 1 (satu). Dari seluruh ruangan yang berada pada lantai dua hanya satu kelas yang berada pada kategori kurang (K) yaitu R.16 (37,74\%) untuk cahaya matahari optimal. Sedangkan, ruangan lainnya kondisi cahaya optimal berada pada kategori cukup (C). Cahaya optimal paling baik berada pada R.29 yang terletak pada orientasi U+30 dengan rata-rata pada kelas tersebut 58,54\% (gambar 11 kanan bawah). Pada lantai 2 jika dirata-ratakan kondisi UDI terpenuhi terbaik maka didapatkan ruang-ruang yang berada pada orientasi $\mathrm{B}+30$ dengan nilai 52,30\% (lihat gambar 11 untuk kondisi detailnya). Kondisi terbaik berikutnya jika diurutkan adalah U+30 (51,85\%), T+30 (50,29\%) dan S+30 $(48,99 \%)$.

Kondisi tidak terpenuhi pada lantai 2 juga sangat dinamis. Pada orientasi $\mathrm{B}+30$ yang merupakan orientasi terbaik untuk ruang kelas pada lantai 2, kondisi tidak terpenuhi disebabkan oleh kondisi cahaya berlebih dengan nilai rata-rata kontribusi UDI>750 Lux 31,59\%. Penyebab situasi ini pada lantai 2 orientasi $\mathrm{B}+30$ ada desain WWR 10,32\% yang bisa dinilai masih kurang baik untuk pencahayaan alami. Sementara situasi konteks di orientasi ini tidak terlalu berperan karena konteks lebih rendah dari bukaan pada ruang kelas di lantai 2 pada orientasi ini. Pada orientasi $\mathrm{T}+30$ kondisi gelap merupakan penyebab utama tidak terpenuhi distribusi cahaya alami dengan nilai rata-rata UDI $<250$ Lux 30,89\%. Kondisi ini juga menggambarkan desain WWR 9,07\% yang bisa dikategorikan kedalam desain yang tidak baik. Pada orientasi ini tidak ada bangunan penghalang lainnya sehingga desain massa dan bukaan berperan penting pada ketidakterpenuhinya pencahayaan alami. Sementara, pada orientasi U+30 dan S+30 kontribusi kelebihan dan kekurangan cahaya memiliki peran yang hampir sama. Pada orientasi U+30 rata-rata UDI $<250$ Lux 25,55\% dan UDI $>750$ Lux $22,60 \%$. Profil penyebab cahaya tidak terpenuhi pada S+30, UDI $<250$ Lux $29,06 \%$ dan UDI $>750$ Lux $21,95 \%$. Pada dua orientasi terakhir ini terlihat desain WWR 10,32\% sedikit lebih baik, hal ini terlihat dari situasi UDI $<250$ Lux dan UDI $>750$ yang relatif kecil dibandingkan dengan orientasi $\mathrm{T}+30$ dan $\mathrm{B}+30$. Kondisi gelap pada R.16 dan R.31 disebabkan oleh perletakan massa bangunan yang membuat overshadow pada dua massa yang berada di orientasi $\mathrm{S}+30$ dan U+30. Lebih detail tentang hal ini bisa dilihat pada gambar 10, 11 dan 12 . 


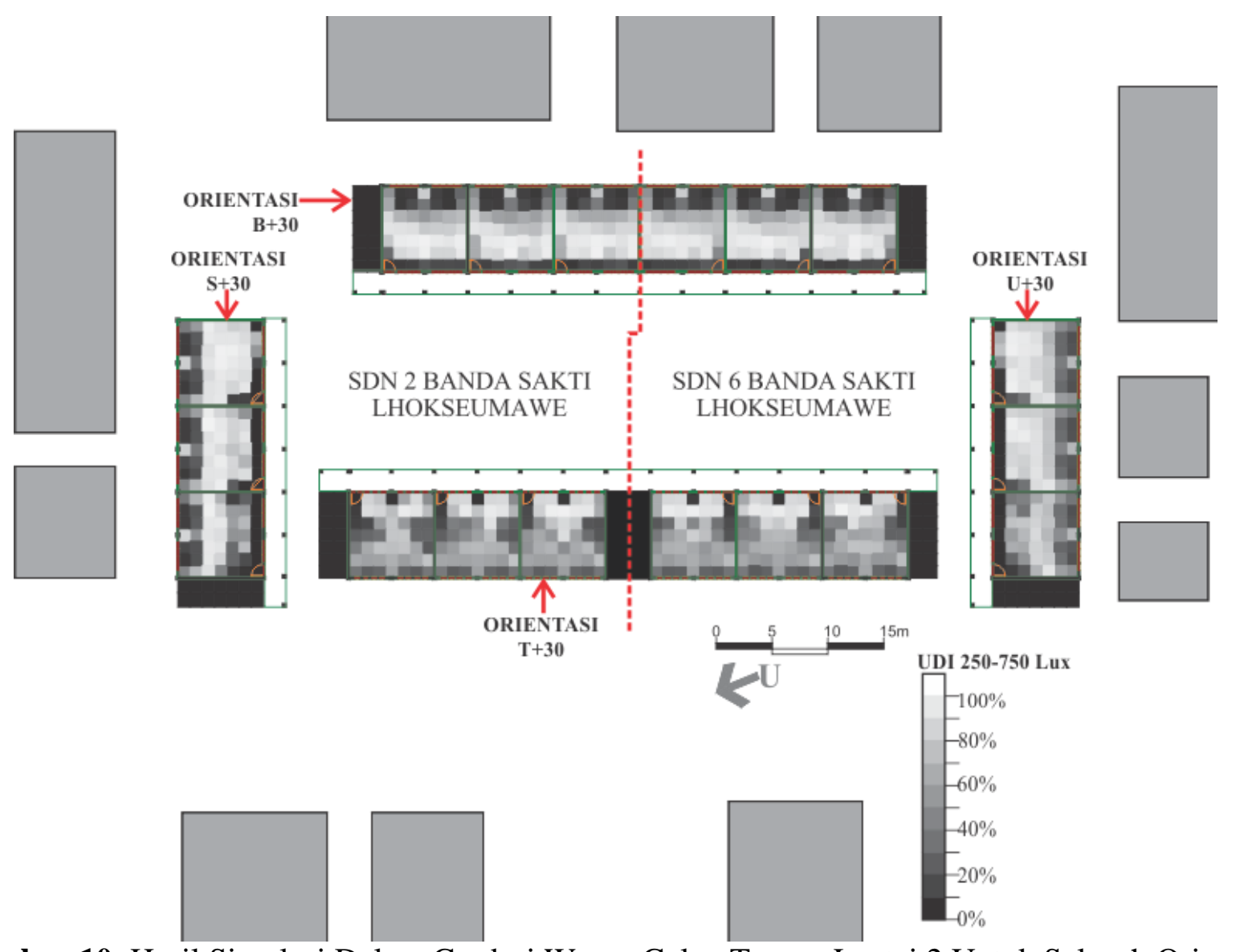

Gambar 10. Hasil Simulasi Dalam Gradasi Warna Gelap Terang Lantai 2 Untuk Seluruh Orientasi Sumber: Penulis, 2019
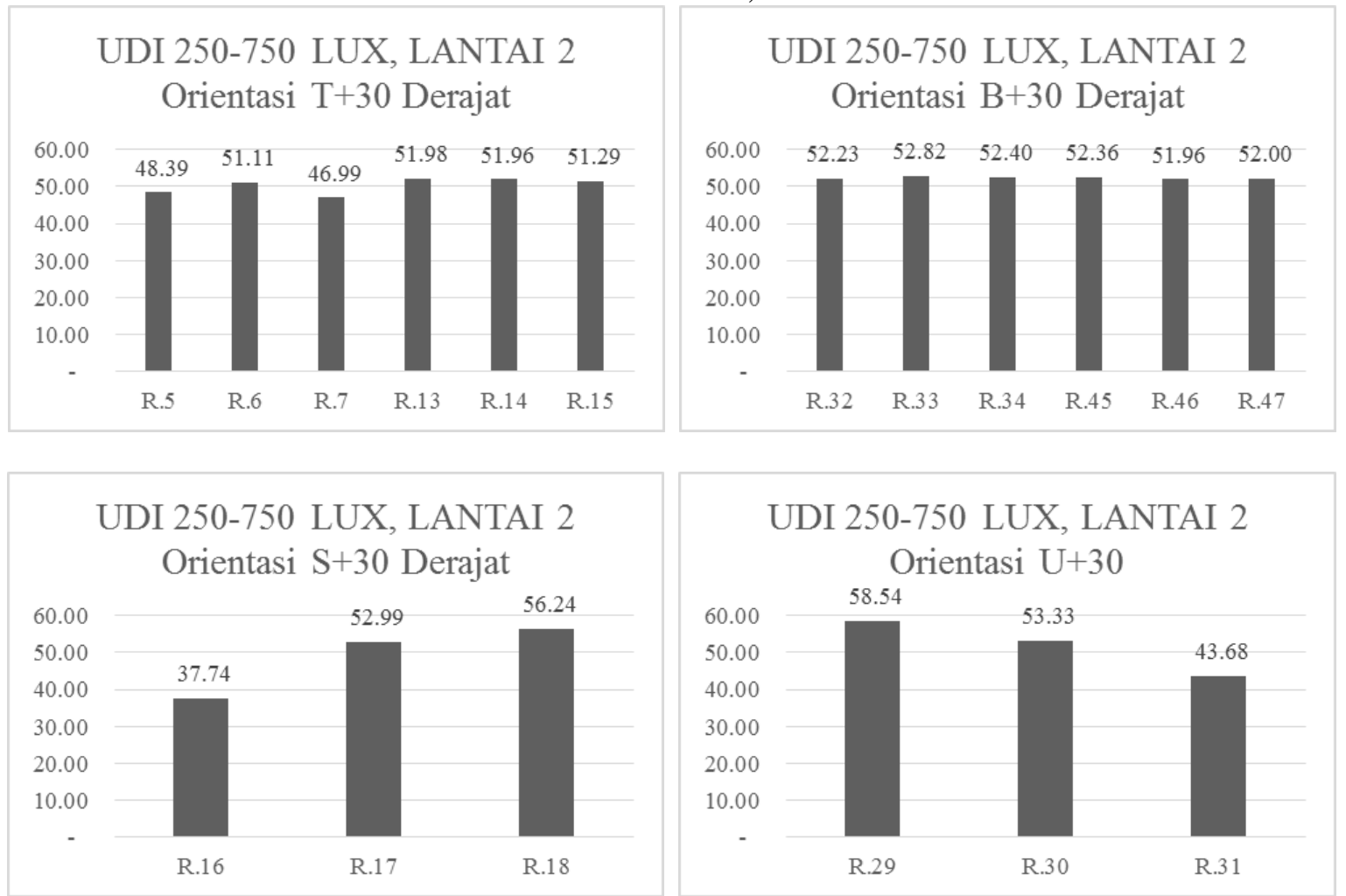

Gambar 11. Grafik Hasil Simulasi Rata-Rata UDI 250-750 Lux Pada Lantai 2 Semua Orientasi Sumber: Penulis, 2019 

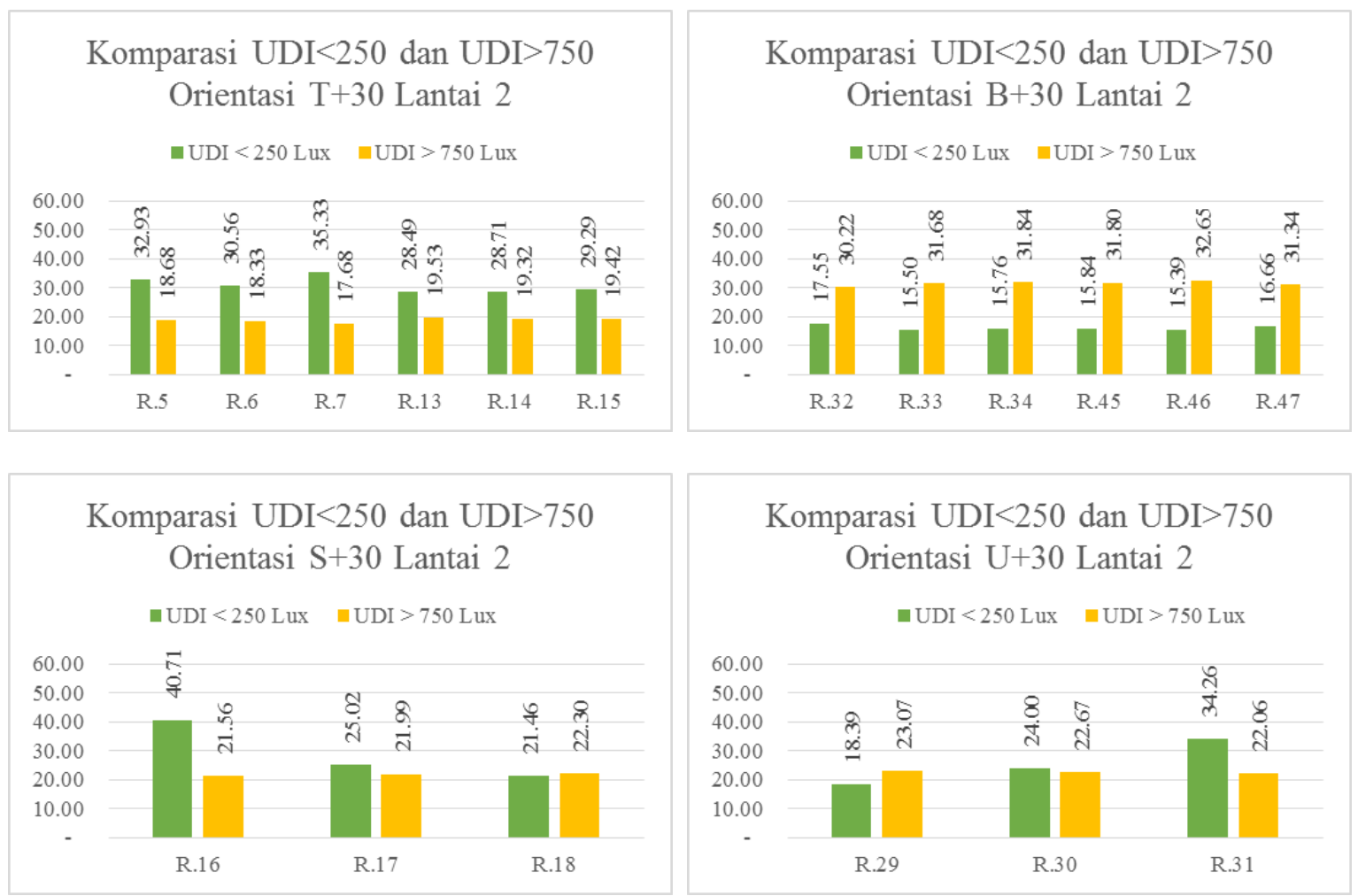

Gambar 12. Grafik Komparasi UDI<250 Lux Dan UDI $>750$ Lux Pada Lantai 2 Semua Orientasi Sumber: Penulis, 2019

\section{Kesimpulan}

Hasil simulasi pada penelitian ini menunjukkan bahwa desain bangunan sekolah yang menjadi objek studi adalah bukan merupakan desain yang ramah terhadap pencahayaan alami. Kondisi iklim tropis yang menyediakan sumber cahaya yang banyak tidak dimanfaatkan dengan baik pada desain ruang kelas pada SDN 2 dan 6 Banda Sakti, Lhokseumawe. Kondisi ini tercermin dari seluruh ruang kelas yang dievaluasi, tidak terdapat satu ruang kelas yang memiliki kondisi pencahayaan alami dengan kategori baik. Hanya terdapat 29 (dua puluh sembilan) atau 80,56\% ruang dengan kategori cukup (C) dan 7 (tujuh) atau 19,44\% ruang dengan kategori kurang (K).

Selanjutnya, dari studi ini mengindikasikan untuk desain sekolah dan ruang belajar pada kawasan urban padat yang baik untuk pencahayaan alami perlu memperhatikan beberapa hal. Pertama, desain massa bangunan dan posisi ruang kelas yang mempertimbangkan arah edar matahari sehingga tidak menghalangi cahaya matahari ke dalam ruang kelas. Kedua, orientasi adalah hal yang sangat penting untuk dipertimbangkan, sebagaimana hasil pada penelitian ini, seharusnya setiap orientasi bukaan pada ruang kelas memiliki WWR masing-masing. Desain WWR yang identik untuk setiap orientasi bukan hal yang dianjurkan untuk desain ruang kelas. Desain WWR ini juga mempertimbangkan kondisi kenyamanan termal ruang dan pandangan. Ketiga, menghindari desain massa bangunan yang memungkinkan terjadinya overshadow dari setiap massa bangunan sekolah. Pengaruh tidak baik self-shadowing terhadap distribusi cahaya alami ditunjukkan seperti pada R.16, R.23, R.24 dan R.31 pada penelitian ini. Keempat, desain massa dan tata letak ruang kelas perlu mempertimbangkan kondisi overshadow dari konteks yang padat. Terakhir, desain WWR yang optimal terhadap pencahayaan alami sebaiknya dipadukan dengan filter cahaya alami seperti bilah- 
bilah horizontal. Studi tentang bilah-bilah horizontal pada fasad bangunan lebih baik dari fasad vertikal dan panel berpori telah dibuktikan pada studi sebelumnya yaitu Atthaillah et al. (2019) dan Atthaillah et al. (2018) untuk kota Lhokseumawe.

\section{Ucapan Terima Kasih}

Penulis ucapkan apresiasi kepada Direktorat Riset dan Pengabdian Masyarakat (DRPM) Kementerian Riset, Teknologi dan Pendidikan Tinggi (Kemenristekdikti) yang telah membiayai penelitian ini lewat skema penelitian dosen pemula (PDP) tahun 2019. Penelitian ini diusulkan ke DPRM Kemristekdikti melalui Lembaga Penelitian dan Pengabdian Masyarakat (LPPM) Universitas Malikusseh. Selain itu penulis juga mengucapkan terima kasih kepada semua pihak yang telah mendukung terlaksananya penelitian ini.

\section{Daftar Pustaka}

Anderson, K. (2014). Design Energy Simulation for Architects. New York: Routledge.

ASHRAE IWEC2 Weather Files. (n.d.). IWEC2 Weather Files. Retrieved April 21, 2019, from White Box Texnologies website: http://weather.whiteboxtechnologies.com/IWEC 2

Atthaillah, A., Bakhtiar, A., \& Badriana, B. (2019). Optimalisasi pencahayaan alami dengan Useful Daylight Illuminance (UDI) pada desain Rumah Toko (RUKO) di Kota Lhokseumawe. Nature: National Academic Journal of Architecture, 6(1).

https://doi.org/https://doi.org/10.24252/nature.v6 i1a2

Atthaillah, Iqbal, M., \& Situmeang, I. S. I. S. (2017). Simulasi Pencahayaan Alami Pada Gedung Program Studi Arsitektur Universitas Malikussaleh. NALARs, 16(2), 113-124. https://doi.org/https://doi.org/10.24853/nalars.16 .2.113-124

Atthaillah, Wijayanti, S., \& Hassan, S. M. (2018). Simulasi Desain Fasad Optimal Terhadap Pencahayaan Alami Pada Gedung Prodi Arsitektur Universitas Malikussaleh. EMARA: Indonesian Journal of Architecture, 4(1), 21-29. https://doi.org/10.29080/emara.v4i1.228

Boubekri, M. (2008). Daylighting, Architecture and Health: Building design strategies. Oxford: Elsevier.

Groat, L., \& Wang, D. (2013). Architectural Research Method (2nd ed.). Canada: John Wiley \& Sons, Inc.

Heschong, L., Wright, R., \& Okura, S. (2000). Daylighting and Productivity: Elementary School Studies, " in Efficiency and Sustanability. Washington.

Idrus, I., Hamzah, B., \& Mulyadi, R. (2016). Intensitas pencahayaan alami ruang kelas sekolah dasar di kota makassar. Simposium Nasional RAPI XV2016 FT UMS, 473-479. Retrieved from https://publikasiilmiah.ums.ac.id/bitstream/handl
e/11617/8076/K22_Irnawaty

Idrus.pdf?sequence $=1$

Khabazi, Z. (2012). Generative Algorithm using Grasshopper. $\quad$ Retrieved from http://www.grasshopper3d.com/page/tutorials-1

Lechner, N. (2007). Heating, Cooling, Lighting: Strategi Desain untuk Arsitektur (2nd ed.). Jakarta: PT Raja Grafindo Persada.

Mediastika, C. E. (2013). Hemat Energi Dan Lestari Lingkungan Yogyakarta: CV Andi Offset.

Nabil, A., \& Mardaljevic, J. (2005). Useful daylight illuminances: a new paradigm for assessing daylight in building. Lighting Research and Technology. https://doi.org/10.1191/1365782805li128oa

SNI 03-6197, A. (2000). Konservasi Energi pada Sistem Pencahayaan. Jakarta: Badan Standardisasi Nasional.

Tedeschi, A. (2014). AAD-Algorithms-Aided Design: Parametric strategies using Grasshopper. Brienza: Le Penseur.

Wibowo, R., Kindangen, J. I., \& Sangkertadi. (2017). Sistem pencahayaan alami dan buatan di ruang kelas sekolah dasar di kawasan perkotaan. Jurnal Arsitektur DASENG, 6(1), 87-98. Retrieved

from https://ejournal.unsrat.ac.id/index.php/daseng/art icle/view/16770/pdf 